Association for Information Systems AIS Electronic Library (AISeL)

PACIS 1997 Proceedings

Pacific Asia Conference on Information Systems

(PACIS)

December 1997

\title{
Executive Information System Failure: A New Zealand Case Study
}

Wendy Bussen

Auckland Institute of Technology

Michael Myers

University of Auckland

Follow this and additional works at: http://aisel.aisnet.org/pacis1997

\section{Recommended Citation}

Bussen, Wendy and Myers, Michael, "Executive Information System Failure: A New Zealand Case Study" (1997). PACIS 1997 Proceedings. 26.

http://aisel.aisnet.org/pacis1997/26

This material is brought to you by the Pacific Asia Conference on Information Systems (PACIS) at AIS Electronic Library (AISeL). It has been accepted for inclusion in PACIS 1997 Proceedings by an authorized administrator of AIS Electronic Library (AISeL). For more information, please contact elibrary@aisnet.org. 


\title{
Executive Information System Failure: A New Zealand Case Study
}

\author{
Wendy S. Bussen \\ Director of Information Services \\ Auckland institute of Technology \\ Auckland, New Zealand \\ Email: wbussen@centre.ait.ac.nz
}

\author{
Michael D. Myers \\ Senior Lecturer \\ Department of Management Science and Information Systems \\ University of Auckland \\ Private Bag 92019, Auckland, New Zealand \\ Tel: +6493737599 ext. 7468 Fax: +64 93737430 \\ Email:m.myers@auckland.ac.nz
}

\section{Executive Summary}

It is well known that Executive Information Systems (EIS) are high risk systems to implement and maintain. Factor research is the most commonly used approach for studying the causes of ElS failure, yet there is no conclusive evidence that the factors suggested in the is research literature ensure system success.

This paper reports on a case study of a failed EIS in a large New Zealand organisation and compares this case with the success factors found in the research literature. One of the findings is that the broader issues surrounding the failure were more significant than the more narrowly focused factors suggested by the factor research approach. These broader issues include the social, cultural, political and economic context of the system as a whole. Another finding was that many of these broader contextual issues were not directly controllable by the EIS project team.

This paper will have implications for all those who have to develop, or are involved with the development of, Executive Information Systems. One important implication is that those involved with the development of EIS can easily overlook the broader contextual issues in EIS implementations, yet these issues are likely to be crucial over the course of a project.

\section{Introduction}

There is little information available to assist practitioners regarding the question of how to minimise the risk of Executive Information System (EIS) failure. A system that provides on-line, summarised and graphical information about a business is desired by many decision makers, but attempts to deliver this type of system have often proven difficult.

Research into the implementation of EIS in the 1980s showed that these systems were expensive to develop and required continual resources to maintain (Burkan, 1991; Rockart and DeLong, 1988). They were designed mainly for larger organisations with mainframe information systems and most of the development time went into creating sophisticated graphical interfaces. Since then information technology has advanced and practitioners are more informed about the nature and use of technology. Research is therefore required to see whether EIS are still high risk systems and if so in what circumstances. Earlier researchers provided a list of factors to take into consideration when implementing an EIS to ensure its success, yet systems still failed even though these factors were addressed. It is possible that other issues may play a bigger influence on the success of EIS than was first envisaged. 


\section{Theoretical Framework}

Factor research is a commonly used approach that attempts to identify those factors (variables) that have the greater influence on implementation success. Quantitative data is collected from a sample of implementation sites in order to determine the relative importance of these variables on the outcomes of implementation (Kwon and Zmud, 1987). Critics of this approach state that it views implementation as a static process instead of a dynamic phenomenon, and ignores the potential for a factor to have varying levels of importance at different stages of the implementation process, and also fails to explain the relationship among the factors (Lucas, 1981). Overall, there is a lack of consistency in the research and very few factors have been shown to be important across multiple studies (Kwon and Zmud, 1987).

Most of the research into EIS failure has resulted in descriptive lists of factors that cause failure. The assumption seems to be that if the practitioner is aware of these factors and addresses them during implementation, then the EIS is more likely to be successful.

Watson and Glover (1989) carried out a study of $21 \mathrm{EJS}$ failures and from their findings identified the following factors that contributed to EIS failure: inadequate or inappropriate technology, failure of the system to meet user needs, lack of executive commitment, and executive resistance to technology. It could be argued that if these are the causes of EIS failure then advances in technology, the advent of sophisticated tools used for prototyping, and the arrival of computer-literate executives should reduce the possibility of EIS failure.

Another descriptive list of factors was identified by Watson (1990). He concluded that ElS failure is more likely to occur if there is a lack of executive support, undefined system objectives, poorty defined information requirements, inadequate support staff and poorly planned evolution. Once again the implicit assumption is that if these factors are minimised then EIS are more likely to succeed.

The narrow focus of factor research has led some researchers to suggest alternative models for IS implementation. Myers (1994) suggests an interpretive approach called critical hermeneutics as one way of conducting research into Is implementation. He argues that critical hermeneutics provides a richer, more integrative view of information systems implementation. It is argued that the researcher should focus on the broader social and historical issues surrounding the implementation of any particular system.

Myers' (1994) approach is consistent with what Walsham (1993) calls an interpretive perspective on information systems. Walsham believes that it is important to have an understanding of the context of the information system and the process whereby the information system influences and is influenced by the context. He defines context as the multi-level identification of the various systems and structures within which the information system is embedded eg the organisation as a whole, the social structures, the minds of the human participants involved with the system including designers, users and any of those affected by the system. He believes that human actors draw on elements of context, such as resources or perceived authority, to carry out actions, and this activity can reinforce existing systems of resource distribution or power, or can create new systems of authority and meaning.

The main difference between the factor research approach and the approach suggested by Myers comes down to one of underlying research assumptions: factor research is based on an underlying mechanistic view of information systems implementation, where researchers try to identify variables associated with some measure of implementation success - it is assumed that each factor is an independent variable and overlooks the interaction between them and other elements in the social and organizational context (Nandhakumar, 1996). Myers' interpretive approach, on the other hand, is based on the assumption that people are active makers of their physical and social reality, and that people are actors not factors. His view is consistent with that of Mouritsen and Bjorn-Andersen (1991), who argue that ". . agents actively construct everyday interaction in accordance with their wants. Humans are not, as seems to be suggested by the idea of "human factor," merely an inactive although problematic part of a system, something that can be optimized through selection, education, and training" (ibid., p. 312).

This broader, interpretive approach to IS research which Walsham and Myers suggest enables researchers to study the wider perspective of the implementation process and to take into account the influence that internal and extemal issues play during information systems implementation. Issues that may influence the success of an IS are the state of the economy, the "health" of the 
business, the culture and the relationship that the executives have with each other and their subordinates. The stability and breadth of the underlying transaction processing systems also play a part in the reliability of the data and the overall success of the EIS.

Influences on IS implementation can also be viewed as either controllable or uncontrollable by the is project team. Factor research identifies factors that are often controllable by the is team, whereas issues identified by the interpretive framework suggested by Myers are usually external and uncontrollable by the project team.

In research on EIS failure special attention has to be given to the fact that 'failure' is a judgement and not necessarily an objective state. Expressions of dissatisfaction which people conclude as failure may be part of a political game of wider dimensions. A system may be perceived as a fallure by one group of stakeholders yet perceived as a success by another group. For example, a project team that implements a sysiem and completes all its tasks on time, within budget and to a satisfactory quality would most likely perceive the EIS implementation as a success, yet if the users never use the system it is likely that the EIS would be labelled as a failure by this group of stakeholders.

\section{Research Method}

In this project the case study research method was used (Yin, 1994). The primary source of information about the system was gathered by one of the authors interviewing the main stakeholders who were involved in the development of the system. A total of six people were interviewed including the designers, developers and the users of the system. The interviews were semi-structured and all were tape recorded and transcribed. Additional information was gathered from other sources such as company documents, newspaper clippings, articles from business magazines and books.

The research took place over a 12 month period during 1995 in Auckland, New Zealand, one year' after the system was abandoned. Although it could be argued that people may have forgotten the facts and the sequence of events of the implementation one year after the fact, the one-year delay meant that the interviewees were relatively open about discussing the system despite their sensitivity about being associated with a failure.

\section{The Case Study: Gardenco}

GARDENCO (a pseudonym) is a well established manufacturing and distribution company in New Zealand. In 1989 the Company Secretary decided that senior management needed an EIS to monitor business performance more closely. Work commenced on the EIS in 1989 but the system was eventually abandoned in 1994.

GARDENCO was founded 160 years ago as a family business in England, and in 1883 a subsidiary was set up in Auckland. The company was run by conservative management until the 1980 s when its management went through extensive restructuring as a result of five changes in ownership (including one of statutory management). During 1989 and 1994 GARDENCO had 7 branches in New Zealand and approximately 250 staff, with its main business focus on seed and bulb production, plant health, and consumer products. The company had an international focus and was both an importer of raw materials and exporter of seed products to over 80 countries. It became a world-wide market leader in packet seeds during this period, and in 1991 it moved into the Japanese market as an exporter of bark products.

The company experienced steady growth during 1989 to 1994, even though many companies in NZ were struggling financially because of the effect of an economic downturn. Management stated that during economic downturns in the economy the gardening industry often experiences accelerafed growth in sales and they believe that this is because people revert to gardening during difficult times.

\section{A brief synopsis of the implementation of the ElS}

In 1989 the company secretary proposed an EIS to senior management and in early 1990 an external consultant was employed to develop an EIS requirements document. No progress was made on the system for eight months until a new MIS manager joined the company and the document was reintroduced. In 1991 the company secretary left and a new company secretary was employed. The new company secretary supported the EIS, and the consultant and the MIS manager continued their evaluation of suitable EIS packages. Unfortunately no packages were found and the decision was made to develop the system in-house. Approval for expenditure was given by the Australian parent company and in 1992 a project team was formed to monitor the development of the new system. 
The EIS was completed in 1993 and all senior managers were trained on a one-to-one basis. Some managers started to use the system on a regular basis but the accuracy of the data was always being questioned. Later that year the MIS manager resigned and her technician became the new MIS manager. In 1994 the parent company stopped all expenditure on developing new systems and the EIS was abandoned.

\section{What went wrong}

The next section draws out the issues of "what went wrong" in the opinion of the main stakeholders:

The consultant believed that the time taken for gathering requirements through to delivering the system was too long.

The Company Secretary believed that the system was on track and was going to succeed at the time that he left the organisation, however he could see that money was going to be a restrictive factor.

“... I think that the cost was going to be a problem ... it needed to push at a pretty senior level. I don't know whether the new company secretary followed on from me. I think she would have probably seen it as one of her lesser priorities because she had so many things that she had to get up to speed on. From the MIS Manager's viewpoint it was a big project and the IS department couldn't do it alone. This was a job being done for senior management and you needed them to provide feedback as to whether it was good, bad or indifferent and I don't know whether this happened after I left."

When the company secretary left he was comfortable with the progress of the system and had no doubts that it would be successful. He also had full confidence in the software house that was doing the programming as it was the same company that had written their sales analysis package which was working well. In his opinion one of the reasons why the system may have failed was because no one at a senior level had the same belief in it after he left.

From the MIS Manager's perspective the system was completed (although it was plagued by recurring errors) and it met the initial requirements. Even though there were technical problems with the system and the managers were losing enthusiasm, she believes that the main reason why the system failed was because of the company secretary leaving at a critical stage of development.

The account manager for the manufacturing system, and a member of the project team, believes that the software house that employed the programmer became concemed about the length of time that the system was taking to complete and "ducked for cover" when the system ran into technical difficulties. He also believes that the technology that the company chosen was "not there", in other words their requirements were ahead of their time technically. They spent time waiting for new releases to solve many of the problems and this slowed the project down.

A technician, calied into help the MIS manager, was always doubtful about the system. He stated that:

"We had spent too much money on it to make it work, so we gave up on it. It was difficult to get the data right. There was too much pressure. The data was only summarised once a week on a Friday night and the executives didn't get it until Monday. Nothing was documented. There was no enthusiasm for the EIS. It kept falling over and the requirements had changed. In 1994 it was abandoned. In the manufacturing environment it is important to have real-time data. It must be current." 
Analysis of The Case Study

In the initial stages of the project the EIS appeared to have had a high chance of succeeding; the organisation was economically sound and was experiencing high profits, there was support from senior management, requirements were gathered professionally and technical expertise was available for development. The issues that threatened the system were the sponsor leaving during implementation, the time taken to develop the system, the change in staff, and the resulting technical problems.

In this research project the EIS was studied from the perspective of the major stakeholders. All the stakeholders interviewed were cautious about giving their opinions as to why the EIS failed, and no obvious political issues were brought out during any of the interviews. The only possible political influence that arose during the interviews was the negative attitude that the technician had about the system and the possibility of a connection between the MIS manager's resignation and the technician's promotion into that position.

One factor frequently mentioned in EIS research is the need for an executive sponsor and the high risk of failure if the sponsor leaves. This is in fact what happened in the case study yet this reason was refuted by the consultant as being a contributing factor to the system's failure. He felt that the new company secretary supported the new system and became the new sponsor. The funds were made available for the system right through to completion therefore it could be argued that there was commitment from senior management otherwise they would have stopped the expenditure. The initiator of the system definitely had the ability to create enthusiasm among the other executives but it is debatable whether that enthusiasm would have changed the outcome of the system if he had stayed. The new company secretary did support the system, perhaps not in the same way as the predecessor, but it is interesting to note that she was the main and last user of the system. Therefore it would be misleading to say that the system failed just because the original executive sponsor left.

As mentioned earlier Watson (1990) extends the idea of the importance of an executive sponsor by stating that an EIS actually needs a broad base of executive support, but having a broad base means that the system must meet the needs of many executive users. Trying to achieve this can put the system at risk. In reference to the case study it could be argued that the decision not to meet the requirements of a distribution manager narrowed the base of executive support for the EIS and it is likely that he would not have supported more expenditure on it. However if the project team had tried to meet his particular needs it would have widened the scope of the system and more development would have been required.

The EIS in this case study was oriented around the critical success factors of the company in a similar manner to that in the Genericorp case study documented by Watson (1990). Watson stated that this approach runs the risk of what is called the "six month phenomenon" ie. for the first six months everything seems to be going well, but then executive use of the system starts to decline. The same situation occurred in this case. It is possible that by providing key financial information the system did not grow in depth or breadth and it did not allow executives to drill down to the level of detail needed. Watson believes that if the system does not provide information about the work unit or individual critical success factors, or directly support the current strategic objectives, then enthusiasm and interest in it is likely to wane.

One of the advantages of using an EIS is to provide access to external data. This type of data attracts senior management as it puts the user online to other databases and helps them to monitor competitors. Unfortunately the EIS in the case study did not provide this. As in the Marine Midland Bank case discussed by Volonio and Robinson (1990), the system only provided information that was already available to the executives via paper reports. The data on the screen was only refreshed weekly, there were problems in drilling down to a lower level, and there were technical problems in highlighting variances in red. If the system had provided "added value" over and above what was already available the users may have been more enthusiastic about its use. Another approach to this would have been the elimination of the paper reports altogether which would have forced the users to use the system (the sponsor claims he would have actioned this if he had stayed).

Another factor that needs to be addressed in regard to failure is the technical problems that occurred during implementation. There is no doubt that this slowed the implementation down but the problems were overcome and the system delivered as per the requirements. A time delay in implementing a system can cause failure if the business changes and the original specification doesn't meet the 
needs of the users. This did not necessarily happen here as the new company secretary stated that the fundamental information that the system provided was still critical to the operation of the business.

The time delay in delivering the system could have been reduced if the consultant and the MIS manager had been able to find a suitable EIS package that met their needs. To contradict this statement it could be argued that a package may not have met all their needs, and there may have still been limitations because of the need to extract files from the main system.

\section{Applying Critical Hermeneutics}

The critical hemeneutic approach suggests that a researcher should study an information system as part of a complex, intertwined set of social and political interactions within a historical context. If factor research is the only approach used, as Watson did with his studies, then the influence of the surrounding historical, political and social issues tend to be missed and the research "loses" its depth. In other words no system is implemented in a vacuum; if all risk factors are minimised this doesn't necessarily mean that the system will be a success. So what were the historical, social and political issues surrounding this case, and what influence did they have on the success of the system?

The company studied had experienced rapid changes and a succession of new owners within a short period of time. The EIS was suggested during this turbulent era and it was hoped that it would provide the executives with a tool that would give them 'a finger on the pulse'. The company secretary was the initiator of the system and it may be worthwhile to investigate his motivation for wanting an EIS. It is possible that he wanted to be recognised as a manager who was capable of initiating and driving change, or he may have been frustrated by the slow response of the divisional managers in addressing problems.

The MIS Manager found herself in a situation where requirements for the new system had already been determined before she arrived on the scene and extensive development was needed to make it work. She also wasn't in a position to refuse to do it and to start debating its worth with the executives. With not being involved in the gathering of the requirements it is possible that she could have misunderstood the reasons why the system was initiated in the first place. That initial involvement may have helped her understand the system more clearly and to keep in touch with the executive users.

The consultant had the complete support of the executives during the requirements stage. However, the time taken to implement the system did cause problems as he became involved in projects overseas and was unable to see the implementation completed. Unfortunately he was the main link between the team that gathered the requirements and the project team. It is of course possible that he may have foreseen difficulties with its success and deliberately moved onto other systems. The requirements document that he carne up with focused on company performance indicators and by the time the EIS was installed the executives requirements would have most likely changed.

The consultant failed to draw up a full implementation plan from the requirements stage through to delivery of the system, therefore the feasibility of the total project was not addressed when the project was left for long periods of time. He had a project plan for the development of the system (the programming) but not for the total implementation. The absence of an overall plan meant that the EIS lost momentum and it became a low priority in comparison to other systems.

The new company secretary, who joined in 1991, was interested in the system and gave it her full support. However, she states that the political decision made by the Australian parent company to stop all system development gave her no choice but to stop work on it. This is a situation that is likely to cause the abandonment of the system regardless of its quality and its acceptance, especially if it was not in line with the strategic direction of the parent company.

In this case study we can see there were many reasons why the system could have failed, however none of the reasons on their own can be singled out as the reason for failure. It could be argued that the overriding political issue of the Australian parent telling New Zealand that it was to stop development was the real reason for failure. However, this also can be challenged as expenditure and support for maintenance of highly successful systems in large organisations is often found even though there is pressure to conform to another direction and to cut costs. It is possible that the system was failing before this because it was not meeting the executives' needs and the Australian 
request to stop systems development work was a convenient excuse to abandon the system. From this point of view the system was not successful enough to ensure its survival and when pressure was put on the organisation to stop development work the executive support was not there to protect it.

Discussion

Table 1 compares the commonly identified risk factors in the EIS literature with the risk factors identified in GARDENCO. The purpose of this is to see whether there are similarities between the two lists and to draw conclusions as to why the system failed.

By comparing the factors from the literature with those found in this case it can be deduced that a significant number of the factors identified by Watson and Glover (1989), Watson (1990), Volonio and Robinson (1991), and Kuehn and Fleck (1991) were indeed present in the case study, and contributed to its failure. There was a lack of executive commitment and this was caused by the lack of experience with computers, and the system was not meeting all of their needs. The company secretary who initiated the system (the executive sponsor) was ahead of the executive team with regard to experience with computers and he ended up leaving the company. The use of the system required a paradigm shift in thinking and a change in work behaviour. The other executives were not ready for this (organisational readiness) and the introduction of the new EIS alone failed to make this happen.

The drive by the company secretary to have the EIS had an influence on the definition of the objectives and how the user requirements were gathered. The literature identifies the need to link the strategic objectives to the system objectives and this didn't occur as the requirements were based only on sales and financial performance indicators. Technical problems were identified in the literature as a risk factor and the wait for new software releases and the errors in the information put the system at risk. The time taken to complete the system, and the lack of planning, were indeed contributing factors to its failure. 


\begin{tabular}{|c|c|c|}
\hline Factor group & ElS Implementation research & GardenCo Case \\
\hline The Executive & $\begin{array}{l}\text { - executive resistance } \\
\text { - lack of time to learn how to use } \\
\text { the machine } \\
\text { - all information already provided } \\
\text { by a subordinate } \\
\text { - emotional, political, and power } \\
\text { problems } \\
\text { - lack of executive commitment } \\
\text { - absence of an executive } \\
\text { sponsor }\end{array}$ & $\begin{array}{l}\text { - some executives lacked } \\
\text { computer literacy and confidence } \\
\text { - information not of value to } \\
\text { executives as it already existed } \\
\text { on paper } \\
\text { - lack of perceived personal } \\
\text { benefit to executives } \\
\text { - lack of broad base executive } \\
\text { commitment and support } \\
\text { (support mainly from company } \\
\text { secretaries) } \\
\text { - initial executive sponsor leaves } \\
\text { half way through project } \\
\end{array}$ \\
\hline $\begin{array}{l}\text { Defining the } \\
\text { objectives }\end{array}$ & $\begin{array}{l}\text { - failure to define objectives } \\
\text { clearly } \\
\text { - lack of understanding by } \\
\text { executive sponsor }\end{array}$ & $\begin{array}{l}\text { - defined by executive sponsor } \\
\text { and used to convince others } \\
\text { - objectives defined to support a } \\
\text { company secretary and not } \\
\text { robust from organisational } \\
\text { perspective }\end{array}$ \\
\hline $\begin{array}{l}\text { Gathering user } \\
\text { requirements }\end{array}$ & $\begin{array}{l}\text { - designers lack understanding of } \\
\text { executive work } \\
\text { - difficulty in securing sufficient } \\
\text { executive time } \\
\text { - poorly defined information } \\
\text { requirements } \\
\text { - difficulty in defining the critical } \\
\text { success factors (CSF) of the } \\
\text { business } \\
\text { - only providing key financial } \\
\text { information to the strategic } \\
\text { - not linked to } \\
\text { objectives of the organisation } \\
\text { too narrow focus, no external } \\
\text { information }\end{array}$ & $\begin{array}{l}\text { - critical success factors not fully } \\
\text { understood and not incorporated } \\
\text { into EIS } \\
\text { - only existing performance } \\
\text { indicators used (based on sales) } \\
\text { - ElS did not include } \\
\text { manufacturing and distribution } \\
\text { requirements } \\
\text { - requirements narrowly focused } \\
\text { and not overtly strategic } \\
\text { - only one method used to identify } \\
\text { requirements } \\
\text { - external data was not } \\
\text { incorporated } \\
\text { - requirements document was not } \\
\text { kept up-to-date }\end{array}$ \\
\hline $\begin{array}{l}\text { Maintaining } \\
\text { interest and } \\
\text { supporting the } \\
\text { EIS }\end{array}$ & $\begin{array}{l}\text { - inadequate or inappropriate } \\
\text { technology } \\
\text { - failure of system to meet users } \\
\text { needs } \\
\text { - inadequate support staff } \\
\text { - costs too large relative to the } \\
\text { unknown level of benefits } \\
\text { - high expectations of the system } \\
\text { - no planning for evolution }\end{array}$ & 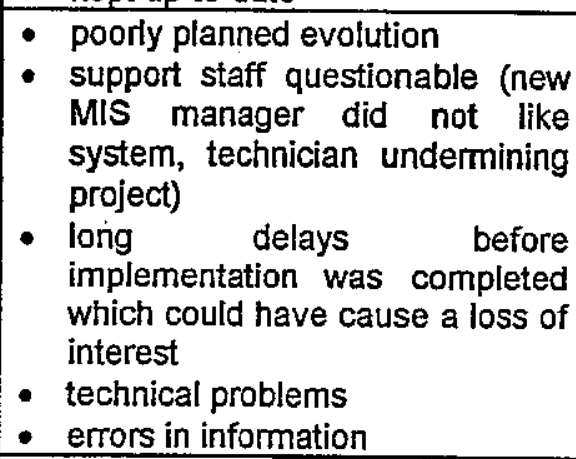 \\
\hline $\begin{array}{l}\text { Organisational } \\
\text { readiness }\end{array}$ & & $\begin{array}{l}\text { - } \begin{array}{l}\text { some executives not ready for } \\
\text { computer-assisted } \\
\text { making }\end{array} \\
\text { - not ready to move from } \\
\text { transaction system to online-EIS }\end{array}$ \\
\hline
\end{tabular}


Even though there were similarities between the factors identified in the EIS literature and those in the case study, these factors alone do not provide a complete picture of the circumstances surrounding the failure. Critical hermeneutics provides a broader context in which to unravel these circumstances further. Table 2 below summarises the broader issues that surrounded the EIS.

\begin{tabular}{|l|l|}
\hline Historical context & $\begin{array}{l}\text { - succession of ownership changes before implementation } \\
\text { - final ownership to an overseas concern } \\
\text { rapid organisational growth }\end{array}$ \\
\hline Political context & $\begin{array}{l}\text { - restriction imposed on IS spending by Australian parent } \\
\text { company } \\
\text { technician unsupportive } \\
\text { company secretary gaining the most benefit from system, } \\
\text { over and above other executives (power issue) }\end{array}$ \\
\hline Social context & $\begin{array}{l}\text { staff changes (complete tumover of key players during } \\
\text { prolonged implementation) }\end{array}$ \\
\hline Economic context & \begin{tabular}{l} 
experiencing growth during depressed NZ economy \\
\hline
\end{tabular}
\end{tabular}

Table 2 Summary of historical, political, social and economic context of the EIS

These broader contextual issues did have an influence on the success of the system and it is possible that they had a greater influence than the narrowly focused factors listed in Table 1. To pinpoint one issue as the overriding reason for the EIS failure would be unwarranted and somewhat subjective on the part of the researcher, as one particular issue did not emerge as being dominant from the data gathered.

\section{Conclusion}

One of the issues which this case highlights is how damaging a long time delay can be to the success of an EIS. If the implementation takes too long then enthusiasm dies and there is a greater chance that there will be a tumover of staff. The speed in delivering a prototype is critical to its success as it helps the executives to understand what an EIS is, how it can assist them and what benefits it will bring.

Perhaps the most important issue which this case highlights becomes clearer if one compares the narrowly focused factors of Table 1 with the broader contextual issues of Table 2 . When the tables are compared it becomes apparent that many of the items can be categorised as either "controllable" or "uncontrollable" from the perspective of the IS project team. The majority of the factors in the case study were within the control of the project team and if they had been identified as risk factors earlier, the practitioners may have had an opportunity to address them. In contrast, all of the contextual issues were uncontrollable by the IS project team, in other words, not within their direct control to change. Awareness of these issues in EIS implementations and the impact of them on the success of a system can easily be overlooked by the project team.

Further research is now required to see whether the combination of factor research and broader approaches such as critical hermeneutics can help identify issues that cause EIS failure, and whether advances in technology will improve the chances of their success in future.

\section{References}

Boland, R.J. "Phenomenology: A Preferred Approach to Research on Information Systems" .: In E. Mumford, R.A. Hirschheim, G. Fitzgerald, and T. Wood-Harper et al. (eds.), Research Methods in Information Systems, New York: North-Holland Publishers, 1985.

Burkan, W.C. Executive Information Systems: From Proposal through Implementation. New York: Van Nostrand Reinhold, 1991.

Kuehn, R., and Fleck Jr.,R.A. "Implementing an EIS in a large Insurance Corporation." Journal of Systerns Management, January, 1991, pp. 6-17.

Kwon, T.H. \& Zmud, R.W. "Unifying the Fragmented Models of Information Systems Implementation".: In R.J. Boland and R.A. Hirschheim (eds.), Critical Issues in Information Systems Research. New York John Wiley \& Sons, 1987, pp. 227-251. 
Lucas, H.C. Jr. Implementation: The key to Successful Information Systems. New York: Columbia University Press, 1981.

Myers, M.D. "A Disaster for Everyone to See: An Interpretive Analysis of a Fajled is Project". Accounting, Management and Information Technologies, Volume 4(4), 1994, pp. 185-201.

Nandhakumar, J. "Design for Success?: Critical Success Factors in Executive Information Systems Development." European Journal of Information Systems, Volume 5, 1996, 62-72.

Rockart, J.F. \& DeLong, D.W. Executive Support Systems: The Emergence of Top Management Computer Use. Homewood, IL: Dow Jones-Irwin, 1988.

Volonino, L. and Robinson, S. "The experiences at Marine Midland Bank in sustaining an ElS." Transactions of the Ninth international Conference on Decision Support Systems, 1990, pp. 164-172.

Walsham, G. Interpreting Information Systems in Organisations. Chichester. John Wiley and Sons, 1993.

Watson, H.J. "Avoiding Hidden ElS Pitfalls." Computerworld, June 25, 1990, pp. 87-91.

Watson, H.J. and Glover, H. "Common and Avoidable Causes of ElS failure." Computerworld, December 4, 1989, pp. 90-91.

Watson, H.J., Rainer, R.K. and Houdeshel, G. Executive Information Systems. Emergence, Development, Impact. New York: John Wiley and Sons, 1992.

Yin, R.K. Case Study Research: Design and Methods, $2^{\text {nd }}$ ed. Newbury Park: Sage Publications, 1994. 